\title{
PENEGAKAN HUKUM TERHADAP TINDAK PIDANA NARKOTIKA NEW PSYCHOACTIVE SUBTANCES BERDASARKAN UNDANG- UNDANG NOMOR 35 TAHUN 2009 TENTANG NARKOTIKA
}

\author{
Gilang Fajar Shadiq \\ Fakultas Hukum Universitas Katholik Parahyangan \\ Email: gilangfajar63@gmail.com
}

\section{Info Artikel:}

Diterima: 27 Januari 2017

| Disetujui: 21 Februari 2017

| Dipublikasikan: 31 Maret 2017

Kata Kunci:

New Psychoactive

Subtances; Asas Legalitas;

Kebijakan Formulasi.

\begin{abstract}
Abstrak
Seiring dengan perkembangan teknologi dan informasi yang sangat pesat jenis-jenis narkotika dan psikotropika bertambah banyak, jenis-jenisnya pun yang beredar di kalangan pecandu makin bervariasi pula. Zat tersebut dikenal dengan nama New Psychoactive Subtances. Tujuan dari penelitian ini adalah untuk mengetahui Apakah terhadap pelaku Tindak Pidana Narkotika NPS (New Psychoactive Subtances) yang belum diatur dalam Lampiran Golongan Narkotika dapat dikenakan ketentuan hukum di dalam Undang-Undang Nomor 35 Tahun 2009 Tentang Narkotika dan Bagaimana kebijakan formulasi terhadap tindak pidana narkotika Tindak Pidana Narkotika NPS (New Psychoactive Subtances). Penelitian ini menggunakan pendekatan yuridis-normatif. Kesimpulan penelitian ini adalah dengan adanya asas legalitas tidak dimungkinkan penerapan Undang-Undang Nomor 35 Tahun 2009 Tentang Narkotika terhadap Tindak Pidana Narkotika New Psychoactive Subtances (NPS) dikarenakan narkotika yang disalahgunakan harus terlebih dahulu masuk ke dalam Lampiran Undang-Undang dan terhadap Undang-Undang Nomor 35 Tahun 2009 Tentang Narkotika perlu untuk diadakan perubahan.
\end{abstract}

\section{LAW ENFORCEMENT AGAINST CRIME NARCOTICS NEW PSYCHOACTIVE SUBTANCES OF LAW NO. 35 YEAR 2009 ON NARCOTICS}

Keywords:

New Psychoactive

Subtances; The Priciple

Of Legality; Formulation

Policy.

\begin{abstract}
Along with the development of information technology and rapid types of narcotics and psychotropic multiply, types are also circulating among addicts more varied as well. These substances are known as the New psychoactive Subtances. The purpose of this study was to determine Is the perpetrators of Crime Narcotics NPS (New psychoactive Subtances) that have not been regulated in Appendix Group of Narcotics may be subject to legal provisions in the Act No. 35 Year 2009 on Narcotics and How the policy formulation of the narcotic crime Follow Narcotics criminal NPS (New psychoactive Subtances). This study uses literature study. It is concluded that the presence of the principle of legality is not possible implementation of Law No. 35 Year 2009 on Narcotics against Crime Narcotics New psychoactive Subtances (NPS) due to drug misuse must first go into the Attachment Act and the Act No. 35 Year 2009 on Narcotics need for the amendment.
\end{abstract}




\section{A. PENDAHULUAN}

Pada saat ini Indonesia sedang mengalami darurat narkoba, berdasarkan hasil penelitian Badan Narkotika Nasional bekerjasama dengan Pusat Penelitian Kesehatan Universitas Indonesia Tahun 2014 tentang Survei Nasional Perkembangan Penyalahgunaan Narkoba di Indonesia, diketahui bahwa angka prevalensi penyalahguna Narkoba di Indonesia telah mencapai $2,18 \%$ atau sekitar 3,8 juta sampai 4,1 juta orang yang pernah pakai narkoba dalam setahun terakhir (current users) pada kelompok usia 10-59 tahun. ${ }^{1}$

Sedangkan berdasarkan penggolongan kasus Narkoba Tahun 2014, terjadi trend peningkatan kasus narkotika dengan persentase kenaikan 8,32\% dari 21.269 kasus di tahun 2013 menjadi 23.038 kasus di Tahun 2014. Sedangkan trend penurunan kasus terbesar yaitu kasus psikotropika dengan persentase penurunan 48,01\% dari 1.612 kasus di tahun 2013 menjadi 838 kasus di Tahun 2014. ${ }^{2}$

Data tersebut di atas menunjukkan bahwa saat ini permasalahan narkoba menjadi permasalahan yang serius bagi bangsa Indonesia. Selain permasalahan mengenai naiknya jumlah penyalahguna narkoba dan naiknya jumlah kasus narkotika, saat ini timbul permasalahan dengan adanya narkotika dan psikotropika jenis baru yang beredar di Indonesia.

Seiring dengan perkembangan teknologi dan informasi yang sangat pesat jenis-jenis narkotika dan psikotropika bertambah banyak, jenis-jenisnya pun yang beredar di kalangan pecandu makin bervariasi pula. Bukan lagi sebatas ekstasi ataupun sabu-sabu seperti yang dikenal luas selama ini, melainkan telah bermunculan nama-nama baru yang masih terdengar asing di telinga. Apalagi namanya masih sering mengusung nama ilmiah dengan mengacu pada bahan pokok yang dikandungnya sebutlah ganja sintetis (synthetic cannabiods), katinon sintetis (synthetic cathinones) serta phenetylamines. Semuanya bersifat adiktif yang memberikan efek depresan, stimulant, euphoria, dan halusinogen. ${ }^{3}$

United Nations Office on Drugs and Crime (UNODC) menyebut zat-zat serupa narkotika dan psikotropika baru tersebut sebagai New Psychoactive Substances (NPS). Dalam laporan Global SMART Programme yang dibuat oleh United Nations Office on Drugs and Crime (UNODC) ${ }^{4}$ disebutkan bahwa:

"These new psychoactive substances (NPS) have been known in the market by terms such as "designer drugs", "legal highs", "herbal highs", "bath salts", "research chemicals", "laboratory reagents"

1 Badan Narkotika Nasional, Jurnal Data P4GN (Pencegahan dan Pemberantasan Penyalahgunaan dan Peredaran Gelap Narkoba), Jakarta: Badan Narkotika Nasional, 2014, hlm. 3.

2 Ibid., hlm. 4.

3 Ibid.

4 United Nations Office on Drugs and Crime, Global SMART Programme: The Challenge Of New Psychoactive Substances, Vienna: United Nations Publication, 2013, hlm. 1. 
Lebih lanjut dalam laporan Global SMART Programme disebutkan bahwa:

"New psychoactive substances are substances of abuse, either in a pure form or a preparation, that are not controlled by the 1961 Single Convention on Narcotic Drugs or the 1971 Convention on Psychotropic Substances"

Single Convention Drugs Tahun 1961 telah diratifikasi melalui Undang-Undang Nomor 8 Tahun 1976 Tentang Pengesahan Konvensi Tunggal Narkotika 1961 Beserta Protokol 1972 yang mengubahnya. Konvensi ini menjadi landasan yuridis dari Undang-Undang Nomor 35 Tahun 2009 Tentang Narkotika sedangkan Convention on Psychotropic Subtances Tahun 1971 diratifikasi melalui Undang-Undang Nomor 8 Tahun 1996 Tentang Pengesahan Convention On Psychotropic Substances 1971 (Konvensi Psikotropika 1971) dan menjadi landasan yuridis dari UndangUndang Nomor 5 Tahun 1997 Tentang Psikotropika.

Terdapat perbedaan antara narkotika dan psikotropika, menurut Pasal 1 Angka 1 Undang-Undang Nomor 35 Tahun 2009 Tentang Narkotika disebutkan bahwa:

"Narkotika adalah zat atau obat yang berasal dari tanaman atau bukan tanaman, baik sintetis maupun semisintetis, yang dapat menyebabkan penurunan atau perubahan kesadaran, hilangnya rasa, mengurangi sampai menghilangkan rasa nyeri, dan dapat menimbulkan ketergantungan, yang dibedakan ke dalam golongan golongan sebagaimana terlampir dalam Undang-Undang ini"
Sedangkan Psikotropika menurut Pasal 1 Angka 1 Undang-Undang Nomor 5 Tahun 1997 Tentang Psikotropika adalah:

"Psikotropika adalah zat atau obat, baik alamiah maupun sintetis bukan narkotika, yang berkhasiat psikoaktif melalui pengaruh selektif pada susunan saraf pusat yang menyebabkan perubahan khas pada aktivitas mental dan perilaku"

Dikarenakan perbedaan tersebut, maka pengaturan mengenai kedua zat tersebut diatur dalam undang-undang yang berbeda, narkotika ke dalam UndangUndang Nomor 22 Tahun 1997 Tentang Narkotika sedangkan psikotropika diatur ke dalam Undang-Undang Nomor 5 Tahun 1997 Tentang Psikotropika. Namun dengan adanya Undang-Undang Nomor 35 Tahun 2009 Tentang Narkotika, Lampiran Undang-Undang Nomor 5 Tahun 1997 Tentang Psikotropika mengenai jenisjenis psikotropika Golongan I dan II dimasukkan ke dalam Lampiran UndangUndang Nomor 35 Tahun 2009 Tentang Narkotika mengenai jenis narkotika Golongan I. Dalam Undang-Undang Nomor 35 Tahun 2009 Tentang Narkotika di bagian Ketentuan Penutup Pasal 153 disebutkan bahwa:

Dengan berlakunya Undang-Undang ini:

a. Undang-Undang Nomor 22 Tahun 1997 tentang Narkotika (Lembaran Negara Republik Indonesia Tahun 1997 Nomor 67, Tambahan Lembaran Negara Republik Indonesia Nomor 3698); dan

b. Lampiran mengenai jenis Psikotropika Golongan I dan Golongan II

5 Ibid., hlm. iv. 
sebagaimana tercantum dalam Lampiran Undang-Undang Nomor 5 Tahun 1997 tentang Psikotropika (Lembaran Negara Republik Indonesia Tahun 1997 Nomor 10, Tambahan Lembaran Negara Republik Indonesia Nomor 3671) yang telah dipindahkan menjadi Narkotika Golongan I menurut Undang-Undang ini, dicabut dan dinyatakan tidak berlaku.

Berdasarkan hal tersebut maka jenis psikotropika yang sering disalahgunakan seperti Ganja, Sabu, dan Ectasy masuk ke dalam Golongan I Narkotika sehingga zatzat tersebut dianggap sebagai narkotika. Setiap penyalahgunaan zat-zat tersebut dapat dikenakan ketentuan hukum yang ada dalam Undang-Undang Nomor 35 Tahun 2009 Tentang Narkotika.

Sedangkan New Psychoactive Subtances (NPS) sendiri merupakan zat-zat yang tidak dikontrol oleh Single Convention Drugs Tahun 1961 dan Convention on Psychotropic Subtances Tahun 1971, jadi di NPS dapat berupa narkotika (narcotic) ataupun psikotropika (Psychotropic). Di Indonesia dikarenakan Pasal 153 UndangUndang Nomor 35 Tahun 2009 Tentang Narkotika yang telah disebutkan di atas maka pengertian NPS adalah zat yang tidak ada dalam lampiran Undang-Undang Nomor 35 Tahun 2009 Tentang Narkotika mengenai jenis narkotika. Dalam Global SMART Programme disebutkan bahwa:

"The term 'designer drugs' had been traditionally used to identify synthetic substances but has recently been broadened to include other psychoactive substances that mimic the effects of illicit drugs and are produced by introducing slight modifications to the chemical structure of controlled substances to circumvent drug controls. I 'Legal highs', 'herbal highs', 'research chemicals' and 'bath salts' are also common names used to refer to NPS offered as a legal alternative to controlled drugs. These substances are frequently labelled as "not for human consumption"

New Psychoactive Subtances (NPS) dibuat dengan memodifikasi struktur kimia dari zat-zat yang telah dilarang dalam Undang-Undang Nomor 35 Tahun 2009 dengan tujuan untuk menghindari jerat hukum, sehingga penyebutan jalanan New Psychoactive Subtances (NPS) adalah Legal Highs. Penyalahgunaan atau peredaran zat tersebut sulit untuk dijerat oleh hukum.

Seperti contoh kasus yang terjadi di Indonesia pada tahun 2014 yaitu kasus penggunaan 3,4 Methylene Dioxy Methcathinon atau biasa disebut Methylone oleh Raffi Ahmad. Zat tesebut tidak masuk ke dalam Lampiran Undang-Undang Nomor 35 Tahun 2009 Tentang Narkotika mengenai jenis narkotika. Hingga saat ini tidak ada kejelasan mengenai proses hukum terhadap Raffi Ahmad tersebut, dikarenakan berkas yang dikirim oleh BNN terus dibalikkan oleh Kejaksaan Agung karena tidak adanya kesepahaman mengenai 3,4 Methylene Dioxy Methcathinon atau biasa disebut Methylone yang saat itu belum masuk dalam lampiran golongan narkotika Undang-Undang Nomor 35 Tahun 2009 Tentang Narkotika.

Sebenarnya dalam Undang-Undang Nomor 35 Tahun 2009 Tentang Narkotika ada instrumen untuk menambah atau 
mengubah lampiran golongan narkotika tersebut yaitu melalui Peraturan Menteri Kesehatan. Dalam Pasal 6 Ayat (3) UndangUndang Nomor 35 Tahun 2009 Tentang Narkotika disebutkan bahwa:

"Kententuan mengenai perubahan
penggolongan narkotika sebagaimana
dimaksud pada ayat (2) diatur dengan
Peraturan Menteri"

Terakhir lampiran golongan narkotika dalam Undang- Undang Nomor 35 Tahun 2009 Tentang Narkotika diubah melalui Peraturan Menteri Kesehatan Nomor 13 Tahun 2014 Tentang Perubahan Penggolongan Narkotika. Zat yang disalahgunakan Raffi Ahmad pun sudah masuk ke dalam Lampiran narkotika tersebut. Namun jenis NPS di dunia sampai dengan Desember 2013 terdapat 348 jenis zat, meningkat dari 251 jenis yang dideteksi pada bulan Juli 2012), jauh melampaui jumlah NPS yang diawasi di tingkat internasional (234 jenis zat). ${ }^{6}$ Saat ini di Indonesia menurut penelitian Balai Laboratorium Badan Narkotika Nasional terdapat 41 jenis NPS (New Psychoactive Subtances) $)^{7}$ yang beredar di Indonesia, dari 41 jenis tersebut baru 18 yang masuk lampiran Undang-Undang Nomor 35 Tahun 2009 Tentang Narkotika. Kemudian di awal Tahun 2017 muncul kembali Peraturan Menteri Kesehatan Nomor 2 Tahun 2017 yang memasukkan tembakau gorilla, tembakau hanoman, spice gold, dan
Legal Herbal ke dalam Lampiran UndangUndang Nomor 35 Tahun 2009 Tentang Narkotika. Permenkes ini muncul ketika ramai kasus Pilot Citilink yang diduga menggunakan tembakau gorilla.

Pada intinya sekalipun tiap tahun ada penambahan daftar narkotika ke dalam Lampiran Undang-Undang Nomor 35 Tahun 2009 melalui Peraturan Menteri Kesehatan tetap saja Narkotika jenis baru akan terus bermunculan dan tidak bisa tersentuh oleh penegakan hukum. Berdasarkan uraian tersebut di atas, dalam penelitian ini terdapat beberapa permasalahan yang timbul, yaitu bahwa New Psychoactive Subtances (NPS) saat ini yang masuk ke wilayah Indonesia adalah sebanyak 41 Jenis, dari ke 41 jenis tersebut hanya 18 yang telah masuk ke dalam Lampiran Golongan Narkotika UndangUndang Nomor 35 Tahun 2009 Tentang Narkotika. Di luar 41 jenis tersebut masih banyak lagi New Psychoactive Subtances (NPS) yang beredar di dunia tapi belum masuk ke wilayah Indonesia. New Psychoactive Subtances (NPS) dapat berupa zat yang benar-benar baru maupun modifikasi dari zat-zat yang dilarang oleh Undang-Undang Nomor 35 Tahun 2009 Tentang Narkotika. Apakah terhadap Pelaku Penyalahgunaan atau Peredaran Gelap NPS (New Psychoactive Subtances) yang belum diatur dalam Lampiran Golongan Narkotika dapat dikenakan ketentuan hukum di dalam Undang-

\footnotetext{
6 Badan Narkotika Nasional, Jurnal Data P4GN (Pencegahan dan Pemberantasan Penyalahgunaan dan Peredaran Gelap Narkoba), Jakarta: Badan Narkotika Nasional, 2015, hlm 2.

7 Balai Laboratorium Badan Narkotika Nasional, Daftar New Psychoactive Subtances (NPS), Jakarta: Badan Narkotika Nasional, 2016.
} 
Undang Nomor 35 Tahun 2009 Tentang Narkotika? serta bagaimana kebijakan formulasi terhadap tindak pidana narkotika gelap Tindak Pidana Narkotika NPS (New Psychoactive Subtances) di masa yang akan datang?

\section{B. PEMBAHASAN}

\section{Teori Kepastian Hukum}

Hukum menghendaki, bahwa manusia dalam situasi konkret tertentu bertindak sesuai dengan apa yang seharusnya dijalankan. Hukum yang ditimbulkan manusia, menguasai hidup manusia. Kepastian hukum merupakan ciri yang tidak dapat dipisahkan dari hukum, terutama untuk hukum yang berbentuk tertulis. Hukum tanpa nilai kepastian akan kehilangan maknanya karena tidak dapat lagi dijadikan sebagai pedoman perilaku bagi semua orang (Ubi jus incertum, ibi jus nullum: di mana tiada kepastian hukum, di situ tidak ada hukum). ${ }^{8}$

Salah satu orientasi dari tujuan hukum menurut Gustav Radbruch adalah kepastian hukum. Menurutnya, kepastian hukum merupakan tuntutan pertama kepada hukum. Tuntutan tersebut ialah supaya ia positif, yaitu berlaku dengan pasti. Hukum harus ditaati, supaya hukum itu sungguh-sungguh positif. ${ }^{9}$

Namun demikian, kepastian hukum itu tidak dengan sendirinya terwujud pada saat diundangkan dan diberlakukannya hukum. Hukum tersebut masih harus diterapkan oleh para penegak hukum (pengemban hukum praktis). Agar kepastian hukum ini dapat benar-benar diwujudkan, maka masih harus diperlukan pula suatu kepastian dalam penerapannya. Hukum Positif atau Teks Otoritatif tersebut mencoba untuk memberikan jawaban atas kebutuhan konkret masyarakat dan sekaligus ditujukan untuk mengupayakan kepastian dan ketertiban. Namun, harus diperhatikan bahwa kepastian dari Teks Otoritatif ini dapat dilemahkan, baik oleh kekaburan hukum maupun oleh perubahan hukum itu sendiri. ${ }^{10}$

Dalam kaitannya dengan teori kepastian hukum ini O. Notohamidjojo mengemukakan berkenaan dengan tujuan hukum yakni: Melindungi hak dan kewajiban manusia dalam masyarakat, melindungi lembaga-lembaga sosial dalam masyarakat (dalam arti luas, yang mencakup lembaga-lembaga sosial di bidang politik, sosial, ekonomi dan kebudayaan), atas dasar keadilan untuk mencapai keseimbangan serta damai dan kesejahteraan umum (bonum commune). ${ }^{11}$

O.Notohamidjojo menempatkan kehadiran hukum dalam hubungan erat dengan manusia dan masyarakat. Habitus hukum yang berpusat pada manusia menjadikan konsep hukum yang dibangun beliau menjalin keselarasan antara rules dan values in social life. Pandangan ini

8 Darji Darmodiharjo \& Shidarta, Penjabaran Nilai-nilai Pancasila Dalam Sistem Hukum Indonesia, Rajawali Pers, Jakarta, 1996, hlm. 44.

9 Krisnajadi, Bab-bab Pengantar Ilmu Hukum Bagian I, Sekolah Tinggi Hukum Bandung, Bandung, 1989, hlm. 60.

10 Disertasi Handy Sobandi, Pembaharuan Hukum Benda Nasional Sesuai Berdasarkan Cita Hukum Pancasila, Universitas Parahyangan, Bandung, 2011, hlm. 82-83.

11 O. Notohamidjojo, Makna Negara Hukum, BPK Gunung Mulia, Jakarta, 1970, hlm. 80-82. 
bukanlah berarti mengikis rule of law yang berkepastian hukum, namun lebih berorientasikan pada menempatkan rule of law pada tujuannya yaitu yang lebih berkeadilan dan memuaskan kebutuhan sosial yang sesungguhnya. ${ }^{12}$

Konsep rule of law sendiri merupakan konsep Anglo Saxon sedangkan dalam konsep Eropa Kontinental dinamakan rechtsstaat (Negara Hukum). Penegasan Negara Indonesia sebagai negara hukum telah dinormativisasi pada Pasal 1 ayat (3) Undang-Undang Dasar 1945 perubahan ke-4 yang menegaskan bahwa "Negara Indonesia adalah negara hukum (rechtsstaat)". Dengan penegasan itu, maka mekanisme kehidupan perorangan, masyarakat, dan negara diatur oleh hukum (tertulis maupun tidak tertulis). Artinya baik anggota masyarakat maupun pemerintah wajib mematuhi hukum tersebut

Dalam teori kepastian hukum serta konsep negara hukum yang menjadi dasar adalah Asas Legalitas yang terdapat dalam Pasal 1 Ayat (1) KUHP (Kitab Undang-Undang Hukum Pidana) yang menyebutkan bahwa:

"Tiada suatu perbuatan dapat dipidana kecuali atas kekuatan aturan pidana dalam perundang-undangan yang telah ada sebelum perbuatan dilakukan"

Ada beberapa hal yang berkaitan dengan asas legalitas. Pertama, prinsip nullum crimen, noela poena sine lege praevia. Artinya tidak ada perbuatan pidana, tidak ada pidana tanpa undang-undang sebelumnya konsekuensi dari makna ini adalah tidak boleh berlaku surutnya ketentuan hukum pidana. Dalam sejarah perkembangan asas legalitas, makna ini telah diadaptasikan di beberapa Negara dengan alasan demi melindungi kepentingan negara dari bahaya yang ditimbulkan terhadap masyarakat. Kedua prinsip nullum crimen, nulla poena sine lege scripta. Artinya tidak ada perbuatan pidana, tidak ada pidana tanpa undangundang tertulis. Konsekuensi dari makna ini adalah harus tertulisnya semua ketentuan pidana. Dengan kata lain, perbuatan yang dilarang maupun pidana yang diancam terhadap perbuatan yang dilarang, harus tertulis secara expresiv verbis dalam undang-undang. ${ }^{13}$

Ketiga, prinsip nullum crimen, nulla poena sine lege certa. Artinya tidak ada perbuatan pidana, tidak ada pidana tanpa aturan undang-undang yang jelas. Konsekuensi selanjutnya dari makna ini adalah bahwa rumusan perbuatan pidana harus jelas, agar tidak bersifat multi tafsir sehingga dapat membahayakan kepastian hukum. Demikian pula dalam hal penuntutan, dengan rumusan yang jelas, penuntut umum akan dapat dengan mudah menentukan mana perbuatanperbuatan yang dikualifikasikan sebagai perbuatan pidana dan mana yang bukan.

12 C. Maya Indah, Refleksi Pemikiran O.Notohamidjojo Untuk Mewujudkan Cara Berhukum Humanis, Disajikan dalam Seminar Nasional Refleksi Pemikiran O.Notohamidjojo Terhadap Perkembangan Hukum di Indonesia, Salatiga, Balairung Utama UKSW, 24 Nopember 2011.

13 Eddy O.S Hiariej, Asas Legalitas dan Penemuan Hukum Dalam Hukum Pidana, Erlangga, Jakarta, 2009, hlm. 4-5. 
Keempat, prinsip nullum crimen, noela poena sine lege stricta. Artinya tidak ada perbuatan pidana, tidak ada pidana tanpa undang-undang yang ketat. Konsekuensi dari makna ini secara implisit adalah tidak diperbolehkannya analogi. Ketentuan pidana harus ditafsirkan secara ketat agar tidak menimbulkan perbuatan pidana baru. $^{14}$

Jauh sebelum lahirnya asas legalitas, prinsipat hukum Romawi memperlihatkan wajah tatanan hukum yang individualistis, sedangkan dalam bidang politik kebebasan warga negara semakin dibelenggu. ${ }^{15}$ Pada zaman Romawi dikenal adanya crimine extra ordinaria yang berarti kejahatankejahatan yang tidak disebut dalam undang-undang. Di antara crimine extra ordinaria ini adalah crimen stellionatus yang secara letterlijk artinya perbuatan jahat atau durjana. Ketika hukum Romawi kuno diterima di Eropa Barat pada abad pertengahan, crimine extra ordinaria ini diterima oleh raja-raja yang berkuasa dan cenderung menggunakan hukum pidana itu sewenang-wenang menurut kehendak dan kebutuhan raja. ${ }^{16}$

Fungsi Asas Legalitas menjadi perhatian Schaaffmeister dan kawankawan yang menyatakan, berlakunya Asas Legalitas bertujuan agar undangundang pidana melindungi rakyat dari pelaksanaan kekuasaan yang tanpa batas dari pemerintah. Ini yang dinamakan fungsi melindungi dari undang-undang pidana. Di samping fungsi melindungi, undang-undang pidana juga mempunyai fungsi instrumental yaitu pelaksanaan kekuasaan pemerintah tegas-tegas diperbolehkan dalam batas-batas yang ditentukan oleh undang-undang. ${ }^{17}$

Fungsi perlindungan hanya ditujukan untuk kepentingan pelaku. Pelaku tidak akan dituntut selama perbuatan mereka bukanlah "Mala Prohibita" (perbuatan yang dilarang undang-undang). Fungsi pembatasan juga hanya ditujukan untuk kepentingan pelaku, karena penguasa tidak dapat menuntut pelaku yang melakukan "crimina extra ordinaria" walaupun menimbulkan kerugian yang luar biasa bagi korban. ${ }^{18}$

Bahwa berdasarkan Asas Legalitas ini terhadap pelaku Tindak Pidana Narkotika New Psychoactive Subtances tidak dapat dijerat dengan UndangUndang Nomor 35 Tahun 2009 Tentang Narkotika dikarenakan jenis narkotika yang digunakan belum masuk ke dalam Lampiran Golongan Narkotika Undang. Pelaku Tindak Pidana Narkotika hanya bisa dijerat apabila narkotika yang disalahgunakan tersebut telah masuk ke dalam lampiran Undang-Undang Nomor 35 Tahun 2009 Tentang Narkotika. Namun peluang untuk menjerat pelaku

14 Ibid., hlm. 5 .

15 John Gillisen Dan Frist Gorle, 2005, Sejarah Hukum: Suatu Pengantar, Refika Aditama, Bandung, hlm. 177

16 Moeljatno, Asas-Asas Hukum Pidana, Rineka Cipta, Jakarta, 2000, hlm. 24.

17 D. Schaffmeister (et al), Hukum Pidana, diedit oleh JE. Sahetapy, Konsorsium Ilmu Hukum Departemen Pendidikan dan Kebudayaan RI bekerjasama dengan Liberty, Yogyakarta, cetakan ke-3, September 2004, hlm. 4.

18 Deni Setyo Bagus Yuherawan, Dekontruksi Asas Legalitas Hukum Pidana: Sejarah Asas Legalitas dan Gagasan Pembaharuan Filosofis Hukum Pidana, Setara Press, 2014, hlm. 6. 
Tindak Pidana Narkotika New Psychoactive Subtances dengan Undang-Undang Nomor 35 Tahun 2009 Tentang Narkotika tetap ada dikarenakan dalam prinsip Asas Legalitas yang keempat yaitu prinsip nullum crimen, noela poena sine lege stricta yang dilarang adalah analogi sedangkan penafsiran ekstensif tidak dilarang.

\section{Teori Penemuan Hukum Oleh Hakim}

Penemuan hukum, demikian orang dapat mengemukakan, mewujudkan inti pengembanan hukum secara ilmiah dan secara praktikal. Dengan pernyataan itu belum diberikan uraian batasan pengertian (definisi) yang memberikan pemaparan tentang apa penemuan hukum itu sesungguhnya. ${ }^{19}$

Dalam tradisi keluarga civil law system, norma positif dalam sistem peraturan perundang-undangan dipandang sebagai sumber formal hukum yang paling utama. Hal ini terlebih-lebih sangat ditekankan dalam ranah hukum pidana. Dalam alam pikiran demikian, keberadaan hukum tertulis menjadi sangat penting. Makna hukum tertulis dalam konteks hukum pidana kerap dibatasi denotasinya yaitu hanya berupa undang-undang. Alhasil, undang-undang perlu dibuat selengkap mungkin agar mampu mengakomodasi dan mengantisipasi setiap perilaku pelanggaran hukum. ${ }^{20}$
Pembentukundang-undangumumnya berkeyakinan bahwa undang-undang yang dihasilkannya mampu mengakomodasi dan mengantisipasi pelanggaranpelanggaran hukum terkait dengan materi muatan yang tercantum dalam peraturan tersebut. Jika mengikuti konsepsi teori kehendak dari John Austin, keyakinan demikian dapat dibenarkan mengingat para pembentuk undang-undang sudah memastikan bahwa undang-undang itu dibuat dengan menampung kehendak penuh semua pemangku kepentingan. Oleh sebab itu, undang-undang yang dihasilkan sudah dipastikan telah menampung rasa keadilan dan memuat jaminan kemanfaatan jika diterapkan. Hakim yang menjumpai adanya peristiwa konkret (empiri) yang dihadapkan di muka persidangan, dengan sendirinya tinggal menerapkan saja undang-undang itu. Jadi, menerapkan undang-undang dengan sendirinya sudah menjamin tegaknya keadilan dan kemanfaatan. ${ }^{21}$ Yang Hakim lakukan tersebut merupakan penegakan hukum yaitu untuk menerapkan hukum (law in the book) terhadap peristiwa konkret (empiri)/law in action.

Namun keyakinan seperti di atas sebenarnya hanya sebatas asumsi. Het recht hinkt achter de feiten aan: hukum selalu berjalan tertatih-tatih di belakang peristiwa konkret. Oleh sebab itu, cepat atau lambat, undang-undang akan tertinggal oleh fakta.

19 J.A. Pontier, Penemuan Hukum (Rechtsvinding) diterjemahkan oleh B. Arief Sidharta, Jendela Mas Pustaka, Bandung, 2008, hlm. 1.

20 Sidharta, Penemuan Hukum Melalui Putusan Hakim, Makalah disampaikan pada Acara Pemerkuatan Pemahaman Hak Asasi Manusia Untuk Hakim Seluruh Indonesia di Hotel Grand Angkasa Medan, 2 - 5 Mei 2011, hlm. 1.

21 Ibid. 
Jurang ketertinggalan itu kian melebar seiring dengan berubahnya tatanan sosial tempat hukum itu hidup di dalam alam kenyataannya. Di sinilah terjadi legal gap antara hukum di atas kertas (law in the books) dan hukum yang hidup dalam kenyataan (law in action; the living law) Dalam praktik di ruang-ruang pengadilan, kesenjangan (gap) yang terjadi ini harus disiasati oleh hakim. Hakikat dari tindakan untuk menyiasati kesenjangan inilah yang disebut dengan penemuan hukum (rechtsvinding). ${ }^{22}$

Secara sangat umum orang dapat mendefinisikan penafsiran dan kontruksi hukum sebagai sebuah reaksi terhadap situasi-situasi bermasalah (problematical) yang dipaparkan orang dalam peristilahan hukum. Ia dalam hal itu berkenaan dengan pertanyaan-pertanyaan hukum (rechtsvragen), konflik-konflik hukum atau sengketa yuridikal. Penemuan hukum diarahkan pada pemberian jawaban terhadap pertanyaan-pertanyaan tentang hukum yang ditimbulkan oleh kejadiankejadian konkret. Terkait padanya antara lain diajukan pertanyaan-pertanyaan tentang penjelasan(tafsiran) dan penerapan aturan-aturan hukum, dan pertanyaanpertanyaan tentang makna dari faktafakta yang terhadapnya hukum harus diterapkan. Penemuan hukum, berkenaan dengan hal menemukan penyelesaianpenyelesaian dan jawaban-jawaban berdasarkan kaidah-kaidah hukum, yang lebih atau kurang persis (cermat terinci), mengemukakan bagaimana terhadap berbagai tipe situasi problematik tertentu seyogianya harus diberikan reaksi. ${ }^{23}$

Peradilan dan penemuan hukum oleh hakim adalah sah (legitim), demikian bunyi sebuah pendirian, jika mereka menghasilkan putusan-putusan yang adil. Pendirian yang demikian dalam keumumannya tidak akan lekas menimbulkan perlawanan. Namun masalahnya adalah bahwa ihwalnya tidaklah mudah untuk menetapkan kriteria apa yang harus harus dipenuhi sebuah putusan agar dapat dikatakan sebagai putusan yang adil. Dapatkah misalnya sebuah putusan sudah dapat disebut adil jika ia sesuai dengan tuntutan kepastian hukum, persamaan hukum, atau kewajaran (redelijkheid) dan kelayakan (billijkheid, fairness)? ${ }^{24}$

Undang-Undang No. 48 Tahun 2009 Pasal 10 ayat (1) tentang Kekuasaan Kehakiman menentukan:

"Pengadilan dilarang menolak untuk memeriksa, mengadili, memutus suatu perkara yang diajukan dengan dalil hukum tidak ada atau kurang jelas, melainkan wajib untuk memeriksa dan mengadilinya".

Ketentuan pasal ini memberi makna bahwa hakim sebagai organ utama Pengadilan dan sebagai pelaksana kekuasaan kehakiman wajib hukumnya

\footnotetext{
22 Ibid.

23 J.A. Pontier, Penemuan Hukum (Rechtsvinding) diterjemahkan oleh B. Arief Sidharta, Jendela Mas Pustaka, Bandung, 2008, hlm. 1

24 Ibid., hlm. 9.
} 
bagi Hakim untuk menemukan hukumnya dalam suatu perkara meskipun ketentuan hukumnya tidak ada atau kurang jelas

Selanjutnya dalam Undang-Undang Nomor 48 Tahun 2009 Tentang Kekuasaan Kehakiman dalam Pasal 5 ayat (1) disebut bahwa:

"Hakim dan Hakim Konstitusi wajib menggali, mengikuti, dan memahami nilai-nilai hukum dan rasa keadilan yang hidup dalam masyarakat"

Maksud dari Pasal 5 ayat (1) ini dalam penjelasan Undang-Undang Nomor 48 Tahun 2009 Tentang Kekuasaan Kehakiman disebutkan bahwa ketentuan ini dimaksudkan agar putusan hakim dan hakim konstitusi sesuai dengan hukum dan rasa keadilan masyarakat.

Kata "menggali" biasanya diartikan bahwa hukumnya sudah ada, dalam aturan perundangan tapi masih samarsamar, sulit untuk diterapkan dalam perkara konkrit, sehingga untuk menemukan hukumnya harus berusaha mencarinya dengan menggali nilai-nilai hukum yang hidup dalam masyarakat. Apabila sudah ketemu hukum dalam penggalian tersebut, maka Hakim harus mengikutinya dan memahaminya serta menjadikan dasar dalam putusannya agar sesuai dengan rasa keadilan yang hidup dalam masyarakat. ${ }^{25}$

Penemuan Hukum dilakukan dapat dilakukan dengan metode interpretasi dan metode kontruksi hukum. Metode interpretasi antara lain adalah interpretasi gramatikal, sistematikal, sejarah undangundang, sejarah hukum, teleological, antisipatif, evolutif-dinamikal, restriktif, dan ekstensif.

Sedangkan metode kontruksi hukum antara lain argumen peranalogian, Metode argumentum a'contrario, Pengkonkretan hukum (Rechtsvervijnings), dan Fiksi Hukum.

Dalam hukum pidana sesuai dengan prinsip asas legalitas yang keempat yaitu prinsip nullum crimen, noela poena sine lege stricta yang artinya bahwa ketentuan pidana harus ditafsirkan secara ketat sehingga tidak menimbulkan perbuatan pidana baru sehingga analogi tidak diperbolehkan. Berbeda dengan analogi, penafsiran ekstensif dalam hukum pidana diperbolehkan walaupun tidak semua ahli hukum sepakat dengan penggunaan penafsiran ekstensif. Hal inilah yang membedakan antara van Bemmelen dan van Hattum di satu sisi dengan Moeljatno di sisi yang lain. Moeljatno dalam hal analogi sependapat dengan van Bemmelen dan van Hattum karena bertentangan dengan asas legalitas. Sementara perbedaan anatara Moeljatno dengan van Bemmelen dan van Hattum adalah masalah penafsiran ekstensif. Moeljatno berpendapat penafsiran ekstensif dapat digunakan dalam hukum pidana, sedangkan van Bemmelen dan van Hattum tidak bisa menerima penggunaan

25 Abdul Manan, Penemuan Hukum Oleh Hakim Dalam Praktek Hukum Acara Di Peradilan Agama, Makalah, Di sampaikan Pada Acara Rakernas Mahkamah Agung RI tanggal 10 s/d 14 Oktober 2010, di Balikpapan, Kalimantan Timur. 
interpretasi ekstensif dalam hukum pidana. ${ }^{26}$

Melalui penafsiran ekstensif, hakim melakukan perluasan makna dari ketentuan khusus menjadi ketentuan umum sesuai kaidah tata bahasanya. Di sini hakim menafsirkan kaidah tata bahasa, karena maksud dan tujuannya kurang jelas atau terlalu abstrak agar menjadi jelas dan konkrit, perlu diperluas maknanya. Misalnya, kata "pencurian barang" dalam Pasal 362 KUHP, diperluas esensi maknanya terhadap "aliran listrik" sebagai benda yang tidak berwujud. Hasil dari penafsiran ekstensif dalam kasus pencurian barang ini adalah barang diartikan luas oleh hakim meliputi juga aliran listrik, tapi tidak menciptakan delik baru melainkan masih tetap pencurian. Berdasarkan esensi makna dan praktik penerapannya, penafsiran ekstensif dilakukan dengan memperluas makna kata atau kalimat yang terdapat dalam suatu peraturan perundangundangan dengan menemukan padanan atau kecocokannya dengan kata atau kalimat yang lain tanpa mengubah atau mengganti substansi maksud dari ketentuan perundangundangan yang ditafsirkan.

Kaitan dengan pembahasan tulisan ini, maka penemuan hukum harus dilakukan hakim dalam mengadili kasus tindak pidana narkotika jenis baru, hal ini dilakukan karena narkotika jenis baru tidak masuk di dalam Lampiran Undang-
Undang Nomo 35 Tahun 2009 Tentang Narkotika. Terdapat contoh kasus tahun 2013 di daerah Nusa Tenggara Barat terdapat kasus serupa dengan Rafi Ahmad yaitu penyalahgunaan narkotika jenis methylone namun dengan peran sebagai pengedar. Para penegak hukum disana berkolaborasi sehingga pelaku bisa dijerat dengan Undang-Undang Nomor 35 Tahun 2009, dalam kasus tersebut hakim melakukan penemuan hukum sehingga memasukan narkoba jenis baru (methylone) ke dalam lampiran Undang-Undang Nomor 35 Tahun 2009 tentang Narkotika. Hakim menganggap bahwa methylone merupakan turunan kathinon sehingga masuk pada lampiran Undang-Undang Narkotika.

Berdasarkan Putusan Nomor 387/ Pid.SUS/2013/PN.Mtr dengan Terdakwa I Wayan Purwa Alias Purwa, yang bersangkutan didakwa oleh Jaksa Penuntut Umum dengan dakwaan Primair Pasal 114 Ayat (1) jo. Ayat (2) yaitu:

“Setiap orang yang tanpa hak atau melawan hukum menawarkan untuk dijual, menjual, membeli, menerima, menjadi perantara dalam jual beli, menukar, atau menyerahkan Narkotika Golongan I, dipidana dengan pidana penjara seumur hidup atau pidana penjara paling singkat 5 (lima) tahun dan paling lama 20 (dua puluh) tahun dan pidana denda paling sedikit Rp1.000.000.000,00 (satu miliar rupiah) dan paling banyak Rp10.000.000.000,00 (sepuluh miliar rupiah)" dan "Dalam hal perbuatan

\footnotetext{
26 Moeljatno, Perbuatan Pidana dan Pertanggungan Jawab dalam Hukum Pidana, Pidato diucapkan pada peringatan Dies Natalis ke VI Universitas Gadjah Mada, di Sitihinggil Yogyakarta pada tanggal 19 Desember 1955.
} 
menawarkan untuk dijual, menjual, membeli, menjadi perantara dalam jual beli, menukar, menyerahkan, atau menerima Narkotika Golongan I sebagaimana dimaksud pada ayat (1) yang dalam bentuk tanaman beratnya melebihi 1 (satu) kilogram atau melebihi 5 (lima) batang pohon atau dalam bentuk bukan tanaman beratnya 5 (lima) gram, pelaku dipidana dengan pidana mati, pidana penjara seumur hidup, atau pidana penjara paling singkat 6 (enam) tahun dan paling lama 20 (dua puluh) tahun dan pidana denda maksimum sebagaimana dimaksud pada ayat (1) ditambah $1 / 3$ (sepertiga)" serta Dakwaan Subsidair Pasal 112 ayat (2) "Dalam hal perbuatan memiliki, menyimpan, menguasai, atau menyediakan Narkotika Golongan I bukan tanaman sebagaimana dimaksud pada ayat (1) beratnya melebihi 5 (lima) gram, pelaku dipidana dengan pidana penjara seumur hidup atau pidana penjara paling singkat 5 (lima) tahun dan paling lama 20 (dua puluh) tahun dan pidana denda maksimum sebagaimana dimaksud pada ayat (1) ditambah $1 / 3$ (sepertiga)".

Terdakwa I Wayan Purwa Alias Purwa saat itu kedapatan membawa 70,9 Gram cristal bening diduga Sabu (Methamphetamine) selain Sabu yang bersangkutan menyimpan 65 butir pil berwarna kuning diduga ektasi (Amphetamine), 87 butir pil berwarna hijau diduga ektasi (Amphetamine) dan 230 butir pil berwarna hijau diduga ektasi (Amphetamine), serta diduga mengedarkannya di wilayah Nusa Tenggara Barat.
Berdasarkan hasil pemeriksaan Laboratoris Kriminalistik No. LAB: 338/ NNF/2013 tanggal 21 Juni 2013, bahwa narkotika yang diduga sabu tersebut benar mengandung sediaan Narkotika MA (Metamfetamina) dan terdaftar dalam golongan I nomor urut 61 Lampiran Undang-Undang Republik Indonesia Nomor 35 Tahun 2009 Tentang Narkotika dan tablet warna kuning, warna hijau benar mengandung Methylone tidak terdaftar dalam Lampiran Undang-Undang Nomor 35 Tahun 2009 Tentang Narkotika.

Kemudian keterangan ahli yaitu Drs. Mufti Djusnir, Apt.,M.Si menyebutkan bahwa struktur dasar methylone adalah analog (Senyawa kimia yang secara struktural mirip dengan yang lain, tetapi sedikit berbeda dalam komposisi ${ }^{27}$ ) dengan struktur molekul methylone dioxy methamphetamine dengan efek farmakologi yang ditimbulkan juga menyerupai methylone dioxy methamphetamine, namun methylone efek yang dihasilkan jauh lebih dahsyat dan lebih merusak susunan syaraf pusat dibanding dengan methylone dioxy methamphetamine, sehingga tidak diragukan lagi bahwa methylone adalah termasuk narkotika golongan I dalam lampiran UU No. 35 Tahun 2009 Nomor urut 37.

Dalam memutus kasus ini, majelis hakim dalam pertimbangan menyebutkan:

1. Menimbang, bahwa zat methylone (tidak terdapat dalam lampiran) dan methcathinone (nomor urut 39 lampiran Undang-Undang Nomor 35

27 Kamus Kesehatan, http://kamuskesehatan.com/arti/analog/ diakses pada 26 Februari 2017. 
Tahun 2009) merupakan derivate dari cathinone yang terdapat dalam daftar narkotika golongan I (nomor urut 35 Lampiran UU Nomor 35 Tahun 2009) dimana struktur dasar dari methylone adalah analog dengan methylone dioxy methamphetamine dengan efek farmakologi juga menyerupai methylone dioxy methamphetamine, namun methylone mempunyai efek yang dihasilkan jauh lebih dahsyat dan lebih merusak susunan syaraf pusat dibanding senyawa methylone dioxy methamphetamine sehingga tidak diragukan lagi bahwa methylone adalah termasuk narkotika golongan I dalam lampiran I UU Nomor 35 Tahun 2009 Tentang Narkotika No. Urut 37.

2. Menimbang, bahwa dengan terdakwa telah mengirim 300 butir methylone pada orang lain, yang kesemuanya atas perintah Roni dari Surabaya, serta methylone mempunyai efek yang dihasilkan jauh lebih dahsyat dan lebih merusak susunan syaraf pusat dibanding senyawa methylone dioxy methamphetamine, maka majelis sependapat dengan saksi ahli Drs. Mufti Djusnir, Apt.M.Si bahwa methylone adalah termasuk narkotika golongan I dalam Lampiran UndangUndang Nomor 35 Tahun 2009 Tentang Narkotika nomor urut 37, oleh karenanya unsur menjadi perantara dalam jual beli narkotika golongan I dalam bentuk bukan tanaman yang beratnya melebihi 5 gram terpenuhi.

Dalam kasus ini hakim melakukan penemuan hukum melalui metode penafsiran ektensif yaitu memasukkan methylone ke dalam lampiran golongan narkotika Undang-Undang Nomor 35
Tahun 2009 Tentang Narkotika, sehingga Nomor Urut 37 dalam lampiran golongan narkotika Undang-Undang Nomor 35 Tahun 2009 Tentang Narkotika yaitu methylone dioxy methamphetamine memiliki makna baru karena termasuk juga methylone. Tapi berbeda dengan analogi yang menciptakan perbuatan baru, dalam kasus ini perbuatannya tetap yaitu mengedarkan narkotika, namun makna dari narkotika ini yang diperluas bukan perbuatannya.

\section{Teori Kebijakan Formulasi}

Istilah kebijakan diambil dari istilah policy (Inggris) atau politiek (Belanda). Kebijakan formulasi dapat diidentikkan dengan kebijakan dalam merumuskan peraturan perundang-undangan. Kebijakan formulasi dalam hukum pidana berarti kebijakan dalam merumuskan norma-norma hukum pidana oleh pihak legislatif. Peranan legislatif meliputi kebijakan dasar yang tidak hanya mengenai pidana yang tepat untuk tiaptiap tindak pidana, tetapi juga mengenai tipe pidana yang disediakan untuk kekuasaan pidana lainnya di tingkat bawah (the other sentencing authorities) dan kadar yang diberikan kepada mereka dalam menetapkan pidana yang tepat untuk seorang pelanggar tertentu ${ }^{28}$

Kebijakan hukum pidana merupakan bagian dari kebijakan legislatif yang lebih spesifik. Istilah kebijakan hukum pidana dapat pula disebut dengan istilah politik

28 Barda Nawawi Arief, Kebijakan Legislatif Dalam Penanggulangan Kejahatan Dengan Pidana Penjara, Univeritas Diponegoro, Semarang, 1994, hlm. 56. 
hukum pidana atau dengan istilah yang lain yaitu penal policy atau criminal law policy atau strafrechpolitiek ${ }^{29}$

Menurut A. Murder strafrechtspolitiek, adalah garis kebijakan untuk menentukan:

a. Seberapa jauh ketentuan-ketentuan pidana yang berlaku perlu diubah dan diperbaharui.

b. Apa yang dapat diperbuat untuk mencegah terjadinya tindak pidana.

c. Cara bagaimana penyidikan, penuntutan, peradilandanpelaksanaan pidana harus dilaksanakan ${ }^{30}$

Sejalan dengan pandangan Marc Ancel dan A. Mulder, menurut Sudarto penal policy dapat diartikan sebagai usaha mewujudkan peraturan perundangundangan pidana yang sesuai dengan keadaan dan situasi pada suatu waktu dan untuk masa-masa yang akan datang. ${ }^{31}$ Sudarto juga menyatakan "bahwa menjalankan politik (kebijakan) hukum pidana juga berarti mengadakan pemilihan untuk mencapai hasil perundangundangan pidana yang paling baik dalam arti memenuhi syarat keadilan dan daya guna. ${ }^{32}$

Teori kebijakan formulasi digunakan untuk mengkaji dan mengevaluasi penerapan Undang-Undang Nomor 35 Tahun 2009 Tentang Narkotika terhadap Pelaku Tindak Pidana Narkotika New Psychoactive Subtances (NPS). Bahwa dalam tulisan ini telah disebutkan dimungkinkan penerapan Undang-Undang Nomor 35 Tahun 2009 Tentang Narkotika terhadap Tindak Pidana Narkotika New Psychoactive Subtances (NPS) sebagai contoh kasus di Nusa Tenggara Barat terdapat contoh Hakim yang melakukan penafsiran ekstensif dengan memasukkan salah satu jenis New Psychoactive Subtances (NPS) ke dalam lampiran Undang-Undang Nomor 35 Tahun 2009 Tentang Narkotika.

Namun dalam penerapan UndangUndang Nomor 35 Tahun 2009 Tentang Narkotika terhadap Tindak Pidana Narkotika New Psychoactive Subtances (NPS) melalui penafsiran ekstensif terdapat beberapa kendala yaitu mengenai kemandirian hakim dalam memutus perkara jadi dalam memutus perkara tersebut tiap hakim berbeda-beda dalam melakukan penafsiran terhadap Tindak Pidana Narkotika New Psychoactive Subtances (NPS). Selain itu dalam tingkat penyidikan dan penuntutan terdapat masalah mengenai penerapan UndangUndang Nomor 35 Tahun 2009 Tentang Narkotika terhadap Tindak Pidana Narkotika New Psychoactive Subtances (NPS) yaitu mengenai perbedaan pandangan tentang apakah terdapat narkotika jenis baru dapat diterapkan Undang-Undang Narkotika, contoh kasusnya adalah kasus penyalahgunaan

29 Barda Nawawi Arief, Bunga Rampai Kebijakan Hukum Pidana (Perkembangan Penyusunan Konsep KUHP Baru), Cet. 3, Kencana Prenada Group, Jakarta, 2011, hlm. 26.

30 Barda Nawawi Arief, Beberapa Aspek Kebijakan Penegakan dan Pengembangan Hukum Pidana, Citra Aditya Bakti, Bandung, 1998, hlm. 3.

31 Sudarto, Hukum Pidana dan Perkembangan Masyarakat, Kajian Terhadap Pembaharuan Hukum Pidana, Sinar Baru, Bandung, 1993, hlm. 9.

32 Sudarto, Hukum dan Hukum Pidana, Alumni, Bandung, 1986, hlm. 19. 
methylone oleh artis Raffi Ahmad yang hingga saat ini tidak ada kejelasan prosesnya dikarenakan berkas perkara dari Badan Narkotika Nasional ditolak oleh Kejaksaaan Agung. Badan Narkotika Nasional yang melakukan Penyidikan berpendapat bahwa narkotika jenis methylone walaupun belum masuk dalam lampiran daftar golongan narkotika namun bisa dikategorikan sebagai narkotika dan bisa diproses dengan Undang-Undang Nomor 35 Tahun 2009 Tentang Narkotika sedangkan Kejaksaan Agung berpendapat bahwa narkotika di luar Lampiran Daftar Golongan Narkotika Undang-Undang Nomor 35 Tahun 2009 Tentang Narkotika bukan merupakan narkotika sehingga berkas perkara dari Badan Narkotika Nasional terus ditolak oleh Kejaksaan Agung.

Intinya bahwa tidak ada keseragaman mengenai penerapan Undang-Undang Nomor 35 Tahun 2009 Tentang Narkotika terhadap Tindak Pidana Narkotika New Psychoactive Subtances (NPS). Dalam Undang-Undang Nomor 35 Tahun 2009 Tentang Narkotika memang terdapat instrumen untuk merubah lampiran Undang-Undang tanpa melalui amandemen yaitu melalui Peraturan Menteri Kesehatan, namun implementasinya Peraturan itu terbit setelah terlebih dahulu masuk jenisjenis narkotika yang baru ke Indonesia, kemudian marak terjadi penyalahgunaan. Kemudian barulah peraturan tersebut terbit, sehingga penulis menyarankan untuk merubah Undang-Undang Nomor 35 Tahun 2009 Tentang Narkotika.
Terdapat beberapa alternatif Kebijakan Formulasi terhadap Pasal 6 dan Lampiran Golongan Narkotika yaitu:

a. Dengan tetap pada ketentuan yang saat ini tanpa merubah UndangUndang Nomor 35 Tahun 2009 serta mengandalkan Peraturan Menteri Kesehatan untuk memasukkan Narkotika jenis baru/New Psychoactive Subtances ke dalam Lampiran Golongan Narkotika Undang-Undang Nomor 35 Tahun 2009 Tentang Narkotika. Konsekuensi dari tidak berubahnya peraturan ini adalah dengan semakin banyaknya jenis narkotika yang baru masuk ke Indonesia maka semakin banyak juga narkotika jenis baru yang tidak terjerat oleh hukum. Peraturan Perundang-undangan akan selalu ketinggalan terhadap perkembangan yang terjadi.

b. Dengan merubah Pasal 6 dan Lampiran Undang-Undang Nomor 35 Tahun 2009 menjadi:

Narkotika sebagaimana dimaksud dalam Pasal 5 digolongkan ke dalam:

1) Narkotika Golongan I;

2) Narkotika Golongan II;

3) Narkotika Golongan III.

4) Semua Turunan dari Narkotika Golongan I, II, III

Dengan perubahan ini maka setiap turunan zat dari narkotika Narkotika Golongan I, II, III yang telah ada dalam Lampiran Undang-Undang Nomor 35 Tahun 2009 bisa dijerat oleh Ketentuan Pidana dalam UndangUndang Nomor 35 Tahun 2009 Tentang Narkotika. Kelemahan dari perubahan 
ini adalah apabila ada zat narkotika yang benar-benar baru terlepas dari zat-zat narkotika yang telah masuk ke dalam lampiran maka terhadap narkotika jenis baru/New Psychoactive Subtances tersebut tidak bisa dijerat oleh Ketentuan Pidana.

c. Dengan meniadakan Lampiran Golongan Narkotika di dalam Undang-Undang Nomor 35 Tahun 2009 Tentang Narkotika sehingga Pasal 6 berubah menjadi:

Narkotika sebagaimana dimaksud dalam Pasal 5 adalah zat atau obat yang berasal dari tanaman atau bukan tanaman, baik sintetis maupun semisintetis, yang dapat menyebabkan penurunan atau perubahan kesadaran, hilangnya rasa, mengurangi sampai menghilangkan rasa nyeri, dan dapat menimbulkan ketergantungan.

Konsekuensi dari perubahan ini adalah tidak adanya kepastian hukum mengenai jenis narkotika dan golongan narkotika, sehingga semua zat yang masuk ke dalam definisi tersebut setiap penyalahgunaannya bisa dijerat oleh hukum.

Dari ketiga alternatif tersebut, penulis berpendapat bahwa Kebijakan Formulasi yang cocok untuk masa yang akan datang yaitu dengan manambahkan Frasa Semua Turunan dari Narkotika Golongan I, II, III ke dalam Pasal 6 UndangUndang Nomor 35 Tahun 2009 Tentang Narkotika. Walaupun dikemudian hari tiap pembuktian di persidangan harus didatangkan ahli untuk menentukan suatu jenis narkotika baru/New Psychoactive
Subtances merupakan turunan dari narkotika yang telah masuk ke dalam lampiran Undang-Undang Nomor 35 Tahun 2009. Tapi hal itu perlu untuk mencegah setiap Tindak Pidana Narkotika New Psychoactive Subtances lolos dari jerat hukum, namun dengan tetap menjaga kepastian hukum. Apabila dibandingkan dengan alternatif ketiga maka alternatif kedua lebih baik karena walaupun dengan alternatif ketiga keadilan pasti tercapai namun kepastian hukum mengenai zat narkotika tidak akan tercapai, dan sangat sulit untuk menentukan berat atau ringannya pidana karena untuk tiap golongan sendiri berbeda-beda hukumannya.

\section{PENUTUP}

Bahwa dalam tulisan ini telah disebutkan dimungkinkan penerapan Undang-Undang Nomor 35 Tahun 2009 Tentang Narkotika terhadap Tindak Pidana Narkotika New Psychoactive Subtances (NPS) sebagai contoh kasus di Nusa Tenggara Barat terdapat contoh Hakim yang melakukan penafsiran ekstensif dengan memasukkan salah satu jenis New Psychoactive Subtances (NPS) ke dalam lampiran Undang-Undang Nomor 35 Tahun 2009 Tentang Narkotika

Bahwa dari beberapa alternatif kebijakan formulasi terhadap UndangUndang Nomor 35 Tahun 2009 maka kebijakan formulasi yang dirasa cocok untuk diterapkan di masa yang akan datang adalah dengan merubah ketentuan Pasal 6 Undang-Undang Nomor 35 Tahun 2009 Tentang Narkotika menjadi: 
Narkotika sebagaimana dimaksud dalam Pasal 5 digolongkan ke dalam:

a. Narkotika Golongan I;

b. Narkotika Golongan II;

c. Narkotika Golongan III.

d. Semua Turunan dari Narkotika Golongan I, II, III

Bahwa penulis menyarankan agar segera dilakukan perubahan UndangUndang Nomor 35 Tahun 2009 Tentang Narkotika, hal ini diperlukan mengingat semakin banyaknya New Psychoactive Subtances (NPS) yang beredar di Indonesia.

\section{DAFTAR PUSTAKA}

Barda Nawawi Arief, Kebijakan Legislatif Dalam Penanggulangan Kejahatan Dengan Pidana Penjara, Univeritas Diponegoro, Semarang, 1994.

Barda Nawawi Arief, Bunga Rampai Kebijakan Hukum Pidana (Perkembangan Penyusunan Konsep KUHP Baru), Cet. 3, Kencana Prenada Group, Jakarta, 2011.

Barda Nawawi Arief, Beberapa Aspek Kebijakan Penegakan dan Pengembangan Hukum Pidana, Citra Aditya Bakti, Bandung, 1998.

Darmodiharjo dan Shidarta, Penjabaran

Nilai-nilai Pancasila Dalam Sistem Hukum Indonesia, Rajawali Pers, Jakarta, 1996.

Fajar, M dan Yulianto, A, Dualisme Penelitian Hukum Normatif dan Empiris, Pustaka Pelajar, Yogyakarta, 2013.
Gillisen, J dan Gorle, F, Sejarah Hukum: Suatu Pengantar, Refika Aditama, Bandung, 2005.

Hiariej, E.O.S, Asas Legalitas dan Penemuan Hukum Dalam Hukum Pidana, Erlangga, Jakarta, 2009.

Krisnajadi, Bab-bab Pengantar Ilmu Hukum Bagian I, Sekolah Tinggi Hukum Bandung, Bandung, 1989.

Lamintang, P.A.F, Dasar-Dasar Hukum Pidana Indonesia, Citra Aditya Bakti, Bandung, 2011.

Marzuki, P.M., Penelitian Hukum, Kencana, Jakarta, 2008.

Marzuki, P.M., Pengantar Ilmu Hukum, Kencana Pranada Media Group, Jakarta, 2008.

Muhammad, A, Hukum dan Penelitian Hukum, Citra Aditya Bakti, Bandung, 2004.

Pontier, J.A, Penemuan Hukum (Rechtsvinding) diterjemahkan oleh B. Arief Sidharta, Jendela Mas Pustaka, Bandung, 2008.

Salman, H.R.O dan Susanto, A.F, Teori Hukum Mengingat, Mengumpulkan, dan Membuka Kembali, Refika Aditama, Bandung, 2013.

Schaffmeister et. al., Hukum Pidana (diedit oleh Sahetapy), Konsorsium Ilmu 
Hukum Departemen P\&K, Liberty, Jogyakarta, 1995.

Sudarto, Hukum Pidana dan Perkembangan Masyarakat, Kajian Terhadap Pembaharuan Hukum Pidana, Sinar Baru, Bandung, 1993.

Sudarto, Hukum dan Hukum Pidana, Alumni, Bandung, 1986.

Rasjidi, L. dan Wyasa P.I.B., Hukum Sebagai Suatu Sistem, Mandar Maju, Bandung, 2003.

Yuherawan, D.S.B, Dekontruksi Asas Legalitas Hukum Pidana: Sejarah Asas Legalitas dan Gagasan Pembaharuan Filosofis Hukum Pidana, Setara Press, 2014.

\section{Jurnal/Majalah}

Badan Narkotika Nasional Republik Indonesia Jurnal Data Pencegahan dan Pemberantasan Penyalahgunaan Narkoba Tahun 2014, Jakarta, 2015.

Badan Narkotika Nasional Republik Indonesia, Pencegahan Narkoba (Handbook Narkotika Nasional)

TIM AHLI BNN RI Petunjuk Teknis Advokasi Bidang Pencegahan Penyalahgunaan Narkoba bagi Lembaga/Instansi, Jakarta, 2010.

\section{Makalah}

Manan, A, Penemuan Hukum Oleh Hakim Dalam Praktek Hukum Acara Di Peradilan Agama, Makalah, disampaikan Pada Acara Rakernas Mahkamah Agung RI di Balikpapan, Kalimantan Timur, 2010.

Sidharta, Penemuan Hukum Melalui Putusan Hakim, Makalah disampaikan pada Acara Pemerkuatan Pemahaman Hak Asasi Manusia Untuk Hakim Seluruh Indonesia di Hotel Grand Angkasa Medan, 2011.

\section{Internet}

www.hariannasional.com, Mafia Narkoba Punya Lab Kembangkan Jenis Baru, diakses pada 8 Agustus 2015 pukul 13.52 WIB.

www. Megapolitan.kompas.com/ read/2013/01/31/1313552/zat.baru. di.narkoba..Raffi sudah.beredar diakses pada 08 Agustus 2015 pukul 14.21.

\section{Disertasi}

Sobandi,H Pembaharuan Hukum Benda Nasional Sesuai Berdasarkan Cita Hukum Pancasila, Disertasi, Universitas Parahyangan, Bandung, 2011. 